\title{
PRECONDITIONS FOR ENHANCING SOCIO- EDUCATIONAL ASSISTANCE TO INDIVIDUALS SERVING NON-CUSTODIAL SENTENCES
}

\author{
Lilia Žukauskienė \\ Klaipèda University, Lithuania \\ Vaidas Viršilas \\ Klaipėda University, Lithuania \\ Probation Department of Klaipėda, Regional Probation Service, Lithuania \\ Carl Åke Farbring \\ Head of a Therapeutic Community in Prison, Sweden
}

\begin{abstract}
The paper focuses on the issue of socio-educational assistance to people prone to criminal behavior, unrelated to the use of psychoactive substances, and serving non-custodial sentences in the Probation Department of Klaipeda Regional Probation Service. It comments on the results of the behavioural correction programme Behaviour-Conversation-Change (BCC) applied to the individuals serving non-custodial sentences. The research was based on the quantitative research strategy. The participants of the research were individuals prone to criminal behavior, unrelated to the use of psychoactive substances, and serving non-custodial sentences in the Probation Department of Klaipeda Regional Probation Service. In the period from 2012 to 2017, 233 respondents took part in the research. The changes in the respondents' motivation were recorded by means of the University of Rhode Island Change Assessment (URICA) 32-item measure, designed to evaluate four key components: precontemplation, contemplation, action, and maintenance (McConnaughy, Prochaska, Velicer, 1983). The changes were evaluated at the beginning and at the end of the programme. As proved by the findings, the impact of the Behaviour-Conversation-Change programme was positive at the precontemplation and the action stages. The results achieved in the application of the Behaviour-Conversation-Change programme meaningfully differed, given the officers' approach to the programme.

Keywords: individuals prone to criminal behavior, unrelated to the use of psychoactive substances, and serving non-custodial sentences; motivational interview; socio-educational assistance.
\end{abstract}

\section{Introduction}

Currently, in most of the Western societies, the priority objective of penal enforcement systems both at the national and global level has been the resocialisation of convicts, their successful return to society, and the management of the risk of re-offending. 
Žukauskiene et al., 2018. Preconditions for Enhancing Socio-Educational Assistance to Individuals Serving Non-Custodial Sentences

Theoretical and empirical research suggests that the individual resocialisation-oriented measures have been more effective than punishment and control of imprisoned people. A progressive penal enforcement policy has been formed by the countries (and particularly Scandinavian ones) where the recidivism and crime rates are the lowest in Europe (Berger, 2016). The probation system in the Nordic countries has been well developed and widely used: thus, e.g., in Sweden in 2012, there were twice more probationers than prisoners per 100,000 inhabitants, and the convicts after serving $2 / 3$ of the sentence were released on probation, part of them under supervision (Ugelvik, 2016). Thus, those countries manage to control the scale of imprisonment and to maintain the smallest numbers of prisoners in Europe. The Norwegian probation system focuses on reintegration and education for independent life and ensures smooth and consistent delivery of social assistance (Ulgevik, 2016).

In accordance with the data of the Republic of Lithuania Department of Statistics as of 1 January 2018, the indicators of criminal offences in Lithuania over the last five years have been decreasing (from 82, 492 criminal offences in 2012 to 59, 075 in 2016). Over the last five years, the number of imprisoned persons has also been consistently decreasing (from 9, 729 in 2012 to 6, 815 in 2016). In accordance with the data of the Lithuanian Probation Service Registry as of 1 January 2018, the number of persons serving non-custodial sentences (including probation) and recorded in the Probation Department Registry did not change significantly (from 8,776 in 2012 to 8,351 in 2016).

The work of law enforcement agencies and progressive criminal and penal policies, consistently pursued by the state and aimed at increasing the opportunities of offenders' behaviour correction in freedom, lead to positive changes in the penal enforcement practice. An improving criminogenic trend is also predetermined by active efforts of probation services to apply effective methods of legal, social, psychological, and educational assistance promoting positive changes in offfenders' behaviour (Žukauskienè, Viršilas, \& Farbring, 2017).

To date, in the discourse of resocialisation of persons prone to criminal behaviour, two models are discussed: the Risk-Need-Responsivity Model, or RNR, and the Good Lives Model, or GLM. The first one, or the RNR, emphasises the importance of risk evaluation, attention to the neutralisation of criminogenic needs, and response through the application of individually chosen programmes, given the offender's personality, motivation, abilities, skills, etc. (Andrews et al., 2011: 738). The second one, or the GLM, accentuates the development of skills to meet the needs for knowledge, health, leisure, community, inner peace, creativity, and other (Ward et al., 2012: 95-97). Measures are proposed that can help implement an individual's wishes in a non-criminal way and to motivate the individual to change (Ward et al., 2012: 95-97). However, as stated by 
D. A. Andrews et al. (2011: 740-741), the reduction of criminogenic needs leads to individual well-being, yet by itself does not ensure the reduction of criminogenic needs.

T. Ward, Sh. Maruna (2007: 81-83) believe that offenders' motivation in the RNR model is a rather problematic issue, as they are seen as potential sources of risk, which makes it more difficult to convince them of the benefit of eliminating risk factors. The RNR representatives (Andrews et al., 2011: 742-743) propose that the problem be solved by motivating employees to build positive relationships with their clients and introduce them to the opportunities for change. In accordance with the GLM model, client motivation starts from the very first interactions with employees through encouraging the clients' willingness to change and revealing the benefits of prosocial behavior. The convict is seen as an active participant who, with the assistance of employees, is able to formulate goals acceptable to the public and to himself (Ward et al., 2012: 106-107). Contemporary versions of the models combine their ideas, and the models are updated conceptually and supplemented with the latest empirical data (Wormith et al., 2012: 112). T. Ward, Sh. Maruna (2007: 81-83) believe that offenders' motivation in the RNR model is a rather problematic issue, as offenders are seen as potential sources of risk, which makes it more difficult to convince them of the benefit of eliminating risk factors.

In order to successfully re-socialise convicts, various offenders' behaviour correction programmes are implemented in the penal enforcement system. The effectiveness of the programmes is ensured by a clearly formulated goal, objectives, and structure, favourable legal regulation, institutional support, professionally trained and motivated employees, community involvement, and continuous monitoring and evaluation of those measures (Lipsey et al., 2007; McGuire, 2008, etc.).

It was cognitive-behavioural therapy (CBT) that was recognised as one of the most effective behaviour corrections (Landenberger \& Lipsey 2005; Hollin, Palmer 2006; Lipsey \& Cullen 2007). The said therapy is based on the assumption that cognitive distortions are not inherent but acquired, therefore, through the CBT, it is possible to change the mindset of offenders, to teach them to solve problems, to identify the risks of criminal behaviour, to develop cognitive and social skills, and to change antisocial behaviour for social (Vaske et al., 2011: 91; Lipsey, Landenberger, \& Wilson, 2007; Lizama et al., 2014). However, the researchers point out that effective cognitive therapy is only possible when the person is already motivated to change (Miller et al., 1988; Miller et al., 1995; Figlie \& Dunn, 2005; Vasilaki et al., 2006; Lundahl \& Burke, 2009), thus creating the preconditions for the application of motivational programmes for behaviour correction.

Motivation is recognized as an important factor that improves the results of 
resocialization (Miller \& Rose, 2009; McMurran, 2009; Austin et al., 2011). The BCC motivational program, conducted through a motivational interview, is suitable for all groups of offenders (Farbring, 2014). Changes in the offender's behaviour are difficult to perceive and are possible even without his own motivation, which is an incentive to act. The BCC program is designed to motivate a client to change his problematic behaviour: to help him analyse his situation, to create the vision of the motivation to change, to make up his mind to change, and to continue to participate in other behaviour changing programmes (e.g., CBT).

Article 18 of the Republic of Lithuania Law on Probation (2011) lays out the forms of probationer's resocialization, including behavioural correction programs. The BCC programme was launched in the Lithuanian Probation Service in 2005 (in 2004, the BCC was developed on the commission of the Swedish Kriminalvarden and used for imprisoned persons and probationers).

In itself, the programme does not guarantee changes in the motivation or behaviour of individuals serving non-custodial sentences, while a motivating interview is not just a set of methods and strategies: a very significant role is played by the the counsellor (Farbring, 2014), as well as his ability to convincingly show willingness to help a client (Saarnio, 2000). It is therefore important how the probation officers implement the BCC programme and how well they have mastered the motivational interview method. In the probation system, the components of socio-educational assistance are the goal of individuals' re-socialization, a constructive interaction of the officer and the offender, the knowledge of the BCC programme methodology, and a favourable psychological climate. Successful education is possible only in an environment where an individual's self-confidence and belief in his own powers is encouraged, his learning power is enhanced, and the belief is promoted that he will be able to act in a certain situation (Jucevičienè, 2013).

The problem. In the penal enforcement system of Lithuania, five adapted and accredited convict behavioural correction programmes are presently carried out. One of them is the Behaviour-Conversation-Change (hereinafter referred to as BCC) programme which aims to increase the internal motivation of an offender to act prosocially (Ehe Official Gazette, 2012, No. 72).

The BCC programme is targeted at all the groups of individuals in the penal enforcement system, especially those with addictions or lengthy criminal life experiences. The current penal enforcement system adheres to the assumption that it is important for individuals prone to criminal behaviour to learn to solve their own problems, to acquire cognitive and social skills, and, most importantly, to be willing to use them.

The research-based effectiveness of socio-educational assistance through the use of the BCC programme to alcohol addicts serving non-custodial sentences was proved by their increasing motivation to change and the determination to 
make use of the acquired skills in life (Žukauskienè, Viršilas, \& Farbring, 2017). However, the effectiveness of socio-educational assistance through the BCC programme to offenders with no addiction to psychoactive substances has not yet been justified by scientific research.

The BCC programme seems to be likely to help individuals having no addiction to psycho-active substances and serving non-custodial sentences in the probation service learn to make decisions to pursue the goals of their lives without violating the law and to develop their social, problem decision, thinking, and selfcontrol skills.

The research aim is to reveal the preconditions of the effectiveness of socioeducational assistance to individuals having no addiction to psycho-active substances and serving non-custodial sentences through the assessment of the impact of the Behaviour-Conversation-Change (BCC) on their motivation to change their criminal behaviour.

\section{Empirical research}

Research methodology. A quantitative research strategy was chosen for the research in accordance with which the knowledge that develops through the prism of the positivist philosophy is based on the observation and measuring of objective reality in order to understand the phenomenon under consideration (Greswell, 2013: p. 36).

Research instrument. The research was carried out, based on the works of foreign authors (Miller \& Rollnick, 1991, 2002; Mc Guire, 2002; Burke et al., 2003; etc) and the methodology of the BCC programme (Farbring \& Berge, 2004) intended for the penal enforcement system institutions. A motivational interview was defined as a way of communication and a method of conversation, based on psycho-social and educational knowledge.

The changes in the behaviour of individuals having no addiction to psychoactive substances and serving non-custodial sentences were recorded by means of the University of Rhode Island Change Assessment (URICA) 32 itemscale, designed to evaluate four key components: pre-contemplation(not ready), contemplation (ambivalence), action, and maintenance (McConnaughy, Prochaska, \& Velicer, 1983). The changes were evaluated in the introductory and final sessions of the BCC programme.

In addition, for the assessment of motivational changes, the Scale (the assessment of three motivation components - desire, ability, and priorities - on the Likert scale from 1 to 10) and the Scales (the data of the assignment of measuring the ratio of the internal and external motivation by dividing 10 weights into two plates, collected in the second and the final sessions of the BCC programme) were chosen. 
Žukauskiene et al., 2018. Preconditions for Enhancing Socio-Educational Assistance to Individuals Serving Non-Custodial Sentences

The methods of statistical analysis: the statistical data analysis was performed using the statistical data processing software IBM SPSS (Statistical Package for the Social Sciences), version 20. To process the data, the following statistical procedures were applied: on the nominal scale, percentage frequencies were calculated in the data distribution; on the ordinal scale, the t-test of two dependent (paired) samples was calculated in the data distribution, and to establish the relationships between variables, the correlation coefficient after Spearman was calculated (Vaitkevičius \& Saudargienè, 2006).

The research participants. The participants of the research were individuals serving non-custodial sentences in the Probation Department of Klaipeda Regional Probation Service and the officers of the Probation Department who carried out the BCC programme. For the research, one of the convict groups was chosen: individuals prone to criminal behaviour and unaddicted to psychoactive substances.

In the period from 2012 to 2017, 233 individuals serving con-custodial sentences took part in the research, and they accounted for the sample of the research. The BCC programme was carried out by 24 officers of the Probation Department.

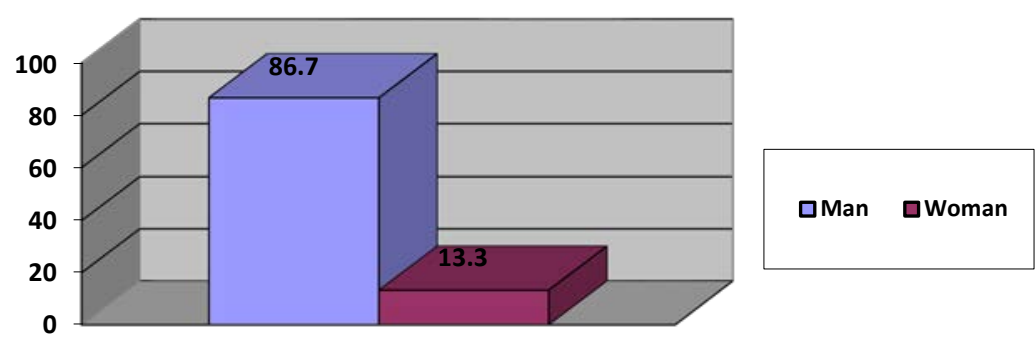

Figure 1 . The characteristics of the respondents by gender $\mathbf{N}=\mathbf{2 3 3}$

As proved by the research data analysis (Fig. 1), the distribution of the respondents $(\mathrm{N}=233)$ by gender was as follows: the majority $(86,7 \%)$ were men, and the minority $(13,3 \%)$ were women. Thus, the majority of individuals prone to criminal behaviour and unaddicted to psychoactive substances were men. However, given the fact that, on the data of 1 January 2018, in the territory of activities of the Probation Department of Klaipeda Regional Probation Service, women accounted for 11,6 \% of the total number (166 out of 1431), one can state that the number of the women- participants of the programme, prone to criminal behaviour and unaddicted to psychoactive substances, was proportionally higher than that of the men. 


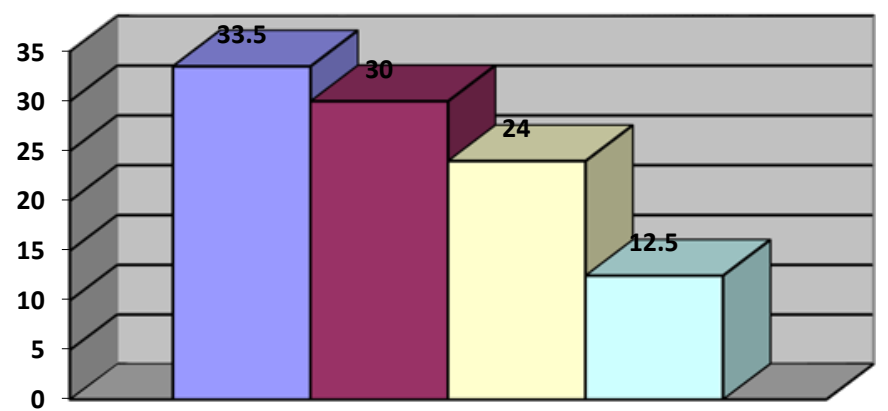

口18 to 28

$\square 29$ to 39

$\square 40$ to 50

$\square 51$ to 61

Figure 2. The characteristics of the respondents by age $\mathbf{N}=\mathbf{2 3 3}$

As proved by the data analysis, the vast majority of the respondents (33,5 \%) were 18 to 28-year-old, slightly over a quarter (30,0 \%), 29 to 39-year-old, almost a quarter of them (24,0\%), 40 to 50-year-old, and the remaining (12,5\%), 51 to 61-year-old. Thus, most frequently, non-custodial sentences were served by individuals prone to criminal behaviour and unaddicted to psychoactive substances who were 18 to 28 year-old, and least frequently, by senior citizens (51 to 61-year-old).

\section{The problem of behaviour}

The majority of the respondents (38,9 \%) named the absence of thinking about the future consequences of their behaviour as the key problem. $31 \%$ during the BCC programme were dealing with the problem of uncontrollable anger, and $20,7 \%$, with the problem of the lack of self-confidence. Other problems (e.g., laziness, etc.) were identified in merely $9,4 \%$ of all cases. To evaluate by gender, the most common problem identified by the men was the absence of thinking about the future consequences of their behaviour (40,8 \%), and only by $25,8 \%$ of the women, while in the case of the women, it was the lack of self-confidence (35,5\%), and only $18,4 \%$ in the case of the men.

The BCC programme was carried out by officers of the Probation Department ( $\mathrm{N}=24)$, therefore, it would be reasonable to identify their education and work experience, i.e. the factors that could have had an impact on the motivation of the convicts and of the individuals prone to criminal activities and unaddicted to psychoactive substances to change. 


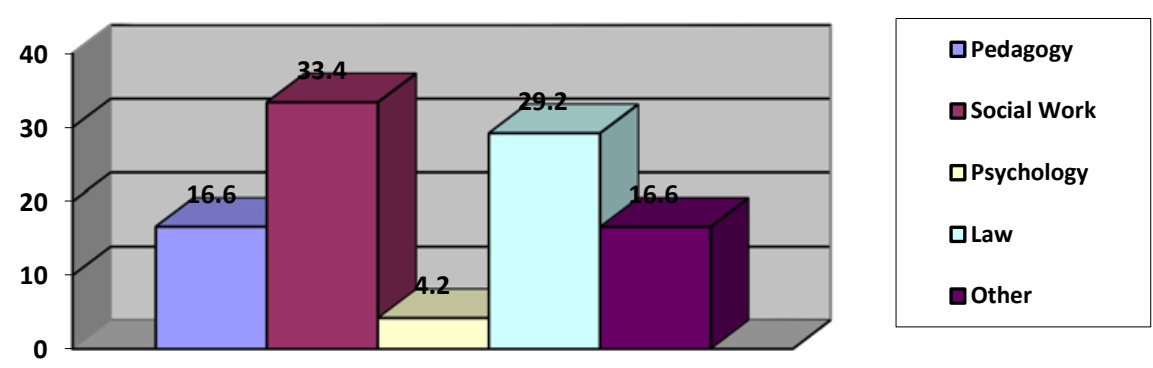

Figure 3. Officers by education $\mathbf{N}=\mathbf{2 4}$

As proved by the research data analysis, the majority of the officers (33,4 \%) had a degree in the field of social work, a slightly smaller part (29,2 \%), in law, and one-sixth each (16,6\%), in the field of pedagogy or in other fields (management, business administration, etc). Only a small proportion of the officers $(4,2 \%)$ had a degree in psychology. However, given the number of the participants that the officers were conducting the BCC programme to, the figures were distributed as follows: the vast majority (66,1 \%) of the respondents participated in the programme conducted by an official with a degree in pedagogy; one-eighth (12,4\%), by an official with a degree in social work, almost one-tenth $(9,9 \%)$ of the respondents participated in the programme conducted by officers with a degree in law or a degree in other fields (management, business administration, etc.). Only an insignificant part of the respondents $(1,7 \%)$ took part in the programme conducted by an officer with a degree in psychology.

The Probation Department of the Klaipeda Regional Probation Service mainly employs officers with a degree in social work and law, however, the BCC programme is mainly conducted by those with a degree in pedagogy and social work. That means that the officers essentially specialise in accordance with the performed functions. The officers most frequently conducting behavioural correction programmes are prepared and able to provide versatile socioeducational assistance to offenders (in our case, to also conduct the BCC programme) and to evaluate changes in the motivation to live a prosocial life of individuals serving non-custodial sentences and prone to criminal behaviour unrelated to the use of psychoactive substances.

\section{Work experience}

The majority (38,0 \%) of the probation system officers had work experience of 0 to 4 years, slightly more than a quarter (29,2\%), from 8 to 12 years, almost one seventh (16,0\%), from 16 to 20 years, and almost one tenth each $(8,4 \%)$, from 4 to 8 and from 12 to 16 years. Thus, most of the officers in the probation 
system were new, and only a small part of them had substantially more extensive work experience. However, given the number of the participants that the officers were conducting the BCC programme to, the figures were distributed as follows: the officers with the work experience of 8 to 12 years worked with the vast majority of the programme participants (69,1\%), those with the work experience from 0 to 4 years, with a smaller segment (13,7\%), and the officers with the work experience of 4 to 8,12 to 16 , and 16 to 20 , with segments from 7,3 \% to $3 \%$. One can argue that most of the probation officers had sufficient experience of work to be able to conduct the BCC programme and to evaluate motivational changes of their participants.

The research findings. To assess the changes in the motivation of the BCC programme participants, the URICA (University of Rhode Island Change Assessment) 32-item scale was used. The changes in the motivation were evaluated by four key components: precontemplation (not ready), contemplation (ambivalence), action, and maintenance (McConnaughy, Prochaska, \& Velicer, 1983).

In order to establish how the BCC programme changed the motivation of the convicts, two measurements were made during the introductory and final sessions. Additionally, their motivation was assessed by means of the Scale and Scales assignments. In the Scale assignment, a 10-point Likert scale was used to assess the client's desire, ability, and priorities to change (as compared with other goals of their lifes). In the Scales assignment, the assessment of the internal and external client's motivation took place by dividing 10 into two plates of the scales. For the final assessment of the Scale and Scales assignment, four estimates were used (desire, ability, priorities, and internal motivation), the sum ranging from 0 to 40 points.

First of all, we intended to establish how the motivation of the BCC programme participants changed in the recognition of the raised problem ( $a$ precontemplation stage). The comparison of the means of the two measurements is presented in Table 1.

Table 1 Comparison of precontemplation before and after the BCC

\begin{tabular}{|l|l|l|l|l|l|l|}
\hline No. & Attribute & $\begin{array}{l}\text { Assessment } \\
\text { mean }\end{array}$ & $\mathbf{N}$ & $\mathbf{t}$ & $\mathbf{d f}$ & $\mathbf{p}$ \\
\cline { 1 - 6 }. & Precontemplation (not ready) 1 & 5,86 & 233 & 3,451 & 232 & 0,001 \\
\hline 2. & Precontemplation (not ready) 2 & 5,23 & 233 & & \\
\hline
\end{tabular}

Upon analysing the data of Table 1 and performing two dependent (paired) samples t-test, it was established that the respondents' precontemplation (not ready) assessment mean at the beginning of the BCC programme was 5,86, and during the final session, 5,23. Thus, the difference between the means was 
Žukauskiene et al., 2018. Preconditions for Enhancing Socio-Educational Assistance to Individuals Serving Non-Custodial Sentences

statistically meaningful $(\mathrm{t}=3,451 ; \mathrm{df}-232 ; \mathrm{p}=0,001)$. High scores in the assessment of the precontemplation (not ready) stage proved that the client refused to admit having the identified problem related to his criminal behaviour and tended to state he had no desire to change. He did not realise that, provided nothing changed, further manifestations of the problem were to cause more serious problems (Farbring, 2014: p. 180). Based on the findings, one can argue that the individuals who completed the BCC programme were more inclined to admit having the identified problem related to their criminal behaviour, and that was the key precondition for changing. Recognition of the problem at the end of the BCC programme was one of the main symptoms witnessing the increased motivation of the individuals to change.

By the research, we sought to assess how the programme participants' motivation changed with regard to contemplation (ambivalence). The comparison of the means of two ambivalence measurements is presented in Table 2.

Table 2 Comparison of ambivalence before and after the BCC

\begin{tabular}{|l|l|l|l|l|l|l|}
\hline No. & \multicolumn{1}{|c|}{ Attribute } & $\begin{array}{l}\text { Assessment } \\
\text { mean }\end{array}$ & $\mathbf{N}$ & $\mathbf{t}$ & $\mathbf{d f}$ & $\mathbf{p}$ \\
\cline { 1 - 6 } 1. & Contemplation 1 & 11,59 & 233 & 0,096 & 232 & 0,923 \\
\hline 2. & Contemplation 2 & 11,56 & 233 & & & \\
\hline
\end{tabular}

Upon analysing the data of Table 2 and performing two dependent (paired) samples t-test, it was established that the respondents' ambivalence assessment mean at the beginning of the BCC programme was 11,59, and during the final session, 11,56. The difference between the means was not statistically meaningful $(t=0,096$; df-232; $p=0,923)$, therefore, one can argue that the ambivalence of individuals who had completed the BCC programme did not change meaningfully. However, in the context of an individual's motivation, the change in ambivalence could not be evaluated unambiguosly. It could indicate the client's readiness to consider the problem in the same way as indicated in the model of contemplation stages by O. Prochaska and C.C. DiClemente (1984). When recording and assessing ambivalence points, attention should be paid to the number of points received in the precontemplation stage. As proved by our research findings, at the end of the BCC programme, the recognition of the problem increased, therefore, non-increasing ambivalence witnessed the fact of the research respondents' knowing that the identified problem caused them difficulties.

By the research, we sought to assess how the programme participants' motivation changed at the level of action. The comparison of the means of two action measurements is presented in Table 3. 
Table 3 Comparison of action before and after the BCC

\begin{tabular}{|l|l|c|l|l|l|l|}
\hline No. & \multicolumn{1}{|c|}{ Attribute } & $\begin{array}{l}\text { Assessment } \\
\text { mean }\end{array}$ & N & t & df & p \\
\hline 1. & Action 1 & 12,28 & 233 & $-6,223$ & 232 & 0,000 \\
\hline 2. & Action 2 & 13,31 & 233 & & & \\
\hline
\end{tabular}

Upon analysing the data of Table 3 and performing two dependent (paired) samples t-test, it was established that the respondents' action assessment mean at the beginning of the BCC programme was 12,28, and during the final session, 13,31 . Thus, the difference between the means was statistically meaningful ( $t=-$ 6,223; df-232; $\mathrm{p}=0,000$ ). High scores in the action assessment witnessed that the client was already coping with his problems and could have felt positive consequences of the change. Changes were taking place, and the client was likely to want assistance to consolidate the change and to avoid relapse. High scores in the area indicated a probability that the change was going to be a success (Farbring \& Berge, 2004: 51; Farbring, 2014: 181).

By the research, we sought to assess how the programme participants' motivation changed with regard to the maintenance attribute. The comparison of the means of two maintenance measurements is presented in Table 4.

Table 4 Comparison of maintenance before and after the BCC

\begin{tabular}{|l|l|l|l|l|l|l|}
\hline No. & Attribute & $\begin{array}{l}\text { Assessment } \\
\text { mean }\end{array}$ & $\mathbf{N}$ & $\mathbf{t}$ & $\mathbf{d f}$ & $\mathbf{p}$ \\
\hline 1. & Maintenance 1 & 7,41 & 233 & 1,767 & 232 & 0,79 \\
\hline 2. & Maintenance 2 & 7,11 & 233 & & \\
\hline
\end{tabular}

Upon analysing the data of Table 4 and performing two dependent (paired) samples t-test, it was established that the respondents' maintenance assessment mean at the beginning of the BCC programme was 7,41, and during the final session, 7,11. The difference between the means was not statistically meaningful $(\mathrm{t}=1,767$; df-232; $\mathrm{p}=0,79)$, therefore, we can argue that the maintenance of the individuals who had completed the BCC programme did not change meaningfully.

By the research, we sought to assess how the programme participants' motivation changed in the Scale and Scales common assessment of the desire, ability, priorities, and inner motivation, the sum ranging between 0 and 40 points. The comparison of the means of two Scale and Scales measurements is presented in Table 5. 
Žukauskiene et al., 2018. Preconditions for Enhancing Socio-Educational Assistance to Individuals Serving Non-Custodial Sentences

Table 5 Comparison of the Scale and the Scales assignments before and after the BCC

\begin{tabular}{|c|c|c|c|c|c|c|}
\hline No. & Attribute & $\begin{array}{l}\text { Assessment } \\
\text { mean }\end{array}$ & $\mathbf{N}$ & $\mathbf{t}$ & df & $\mathbf{p}$ \\
\hline 1. & Desire 1 & 9,07 & 228 & \multirow[t]{2}{*}{$-3,785$} & \multirow[t]{2}{*}{227} & \multirow[t]{2}{*}{0,000} \\
\hline 2. & Desire 2 & 9,45 & 228 & & & \\
\hline 3. & Ability 1 & 8,64 & 228 & \multirow[t]{2}{*}{$-5,365$} & \multirow[t]{2}{*}{227} & \multirow[t]{2}{*}{0,000} \\
\hline 4. & Ability 2 & 9,12 & 228 & & & \\
\hline 5. & Priorities 1 & 7,60 & 228 & \multirow[t]{2}{*}{$-8,301$} & \multirow[t]{2}{*}{227} & \multirow[t]{2}{*}{0,000} \\
\hline 6. & Priorities 2 & 9,32 & 228 & & & \\
\hline 7. & One's own desire 1 & 7,60 & 228 & \multirow[t]{2}{*}{$-9,193$} & \multirow[t]{2}{*}{227} & \multirow[t]{2}{*}{0,000} \\
\hline 8. & One's own desire 2 & 8,59 & 228 & & & \\
\hline 9. & Total score 1 & 34,15 & 228 & \multirow[t]{2}{*}{$-9,830$} & \multirow[t]{2}{*}{227} & \multirow[t]{2}{*}{0,000} \\
\hline 10. & Total score 2 & 36,32 & 228 & & & \\
\hline
\end{tabular}

Upon analysing the data of Table 5 and performing two dependent (paired) samples t-test, it was established that the BCC programme participants' Scale and Scales assignment assessment means at the beginning of the BCC programme were 9,$07 ; 8,64 ; 7,60 ; 7,60 ; 34,15$ respectively, and during the final session, 9,45; 9,12; 9,32; 8,59; 36,32 respectively. Thus, all the differences between the means were statistically meaningful $(\mathrm{t}=-3,785 ;-5,365 ;-8,301 ;-9,193 ;-9,830, \mathrm{df}-227$; $\mathrm{p}=0,000$ ). High scores unambiguously indicated that the motivation of the programme participants to change after the completion of the programme increased.

As proved by the research findings, the answers of the Probation Department officers fell into three groups: the majority of the officers (50,0\%) believed in the effectiveness of the BCC programme; one fourth (25,0\%) had doubts about its effectiveness; and the same segment (25,0\%) did not believe in the programme. However, given the number of the participants that the officers were conducting the BCC programme to, it turned out that the officers who believed in the effectiveness of the programme and were conducting it to the convicts accounted for as many as $87,6 \%$, those in doubt, for $10,3 \%$, and those who did not believe in it, just for 2,1\%. Therefore, one can argue that the vast majority of the probation officers believed in the effectiveness of the BCC programme, and when working with a substantially larger number of convicts, they better specialised in the area. The officers who did not believe in the effectiveness of the BCC programme might have been not totally familiar with its aims, content, and the opportunities of application or have not have mastered effective methods for the work with convicts (see Table 6). 
Table 6 Correlation between the attributes of the convicts' problem recognition and the Probation Department officers' view on the BCC programme effectiveness

\begin{tabular}{|l|c|}
\hline \multicolumn{1}{|c|}{$\begin{array}{c}\text { The convicts' recognition of the } \\
\text { problem }\end{array}$} & $\begin{array}{c}\text { The Probation Department Officers' view on the } \\
\text { BCC programme effectiveness }\end{array}$ \\
\hline Precontemplation 1 & $\mathbf{- 0 , 2 1 8 * *}$ \\
Precontemplation 2 & $\mathbf{- 0 , 1 8 5 ^ { * * }}$ \\
\hline Action 1 & 0,119 \\
Action 2 & $\mathbf{0 , 2 8 0 * *}$ \\
\hline Total sum 1 (Scale and Scales) & 0,117 \\
Total sum 2 (Scale and Scales) & $\mathbf{0 , 2 4 0 * *}$ \\
\hline
\end{tabular}

**The correlation is meaningful at the level of 0,01

Upon the correlation analysis of the data, a weak positive correlation $(\mathrm{r}=$ $0,218)(r=-0,218)(r=-0,218)(r=-0,185)(p<0,01)$ was established betweeen the belief of the probation officers in the BCC programme effectiveness and the programme participants' refusal to recognise their problems at the beginning and the end of the programme, i.e. the more a Probation Department officer believed in the effectiveness of the BCC programme, the less the programme participants were inclined to deny the behavioural problem, identified by themselves, that predetermined their criminal behaviour.

A weak positive correlation $(r=0,280)(p<0,01)$ existed between the belief of the probation officers in the BCC programme effectiveness and the programme participants' action in coping with the behavioural problem identified by themselves at the beginning and the end of the BCC programme, i.e. the more a Probation Department officer believed in the effectiveness of the BCC programme, the better the programme participants were coping with their problem at the end of the BCC programme.

A weak positive correlation $(r=0,240)(p<0,01)$ existed between the belief of the probation officers in the BCC programme effectiveness and the programme participants' motivation assessment results in the Scale and the Scales assignment at the end of the BCC programme, i.e. the more a Probation Department officer believed in the effectiveness of the BCC programme, the higher the client's scores in the Scale and the Scales assignment were at the end of the BCC programme.

Thus, the belief of the officers in the BCC programme effectiveness had a decisive impact on the positive changes in the motivation and behaviour of the convicts who had no addiction to psychoactive substances. Our research confirmed the conclusions previously made by researchers (Moyers, 2003; Žukauskienè, Viršilas, \& Farbring, 2017) about there being no correlation between the counsellor's education and experience and the effectiveness of the assistance rendered by him when encouraging the clients to change; the most 
important factor was the belief of the counsellor in the effectiveness of his assistance.

C. A. Farbring (2014) presumed that the changes in the convict motivation depended not only on the ways the motivational interviews were used, but also on the counsellors' body language, voice, and smile, on whether the client smiled or looked worried when telling some sad story, and on whether the desire to help the client was shown convincingly.

During the BCC programme, the individuals who served non-custodial sentences and had no addiction to psychoactive substances were motivated to change their criminal behaviour. One can argue that further implementation of the programme can produce positive results in increasing the effectiveness of the socio-educational assistance in the probation service and in continuing the correction of criminal behaviour through such psychological measures as cognitive behavioural therapy, etc. As proved by research (Landenberger \& Lipsey 2005; Hollin \& Palmer 2006; Austin et al., 2011, etc.), clients' high motivation to change was an important precondition for further successful behavioural correction.

\section{Conclusions}

The use of the BCC (Behaviour-Conversation-Change) programme in the probation system for people not addicted to psychoactive substances resulted in a positive impact of the programme on the changes in their motivation and behaviour in the stages of precontemplation (not ready) and action (URICA questionnaire) and in the Scale and the Scales assignment.

The recognition of the problem predetermining their criminal behaviour, identified by persons serving non-custodial sentences during the introductory session of the BCC programme, grew in the final stage of the programme. That was one of the key factors witnessing the grown motivation of the programme participants to live without violating the law.

The BCC programme participants who had no addiction to psychoactive substances achieved positive changes at the level of action: they undertook real action in order to live without violating the law (changed the circle of associates, changed the place of residence in a criminal environment, found a job, abandoned risky activities, and, most importantly, continued to take part in the CBT programme or other approved behavioural correction programmes).

A decisive impact on the positive changes in the motivation to live without violating the law of the individuals who had no addiction to psychoactive substances through the BCC (Behaviour-Conversation-Change) programme was made by the belief of the Probation Department officers in the effectiveness of the programme. 


\section{References}

Andrews, D. A., Bonta, J., \& Wormit, J. S. (2011). The Risk-Need-Responsity (RNR) Model Does Adding the Good Lives Model Contribute to Effective Crime Prevention? Criminal Justice and Behavior, Vol. 7 (38), 735-755.

Austin, K. P., Williams, M. W. M., \& Kilgour, G. (2011). The Effectiveness of Motivational Interviewing with Offenders: An Outcome Evaluation. New Zealand Journal of Psychology. Vol. 40, (1), 201.

Berger, R. (2016). Kriminalomsorgen: A Look at the World's Most Humane Prison System in Norway. Access online: https://papers.ssrn.com/sol3/papers.cfm?abstract_id=2883512

Burke, B. L., Arkowitz, H., \& Menchola, M. (2003). The Efficacy of Motivational Interviewing: A Meta-Analysis of Controlled Clinical Trials. Journal of Consulting and Clinical Psychology, Vol. 71 (5), 843-861.

Greswell, J. (2013). Research Design/Qualitative, Quantitative, and Mixed Methods Approaches. Fourth Edition. Thousand Oaks: SAGE Publications.

Hollin, C. R., \& Palmer, E. J. (2006). Offending Behaviour Programmes. Development, Application, and Controversies.

Farbring, C. A. (2014). Handbok I motiverande samta. MI. Natur \& Kultur.

Farbring, C. A., \& Berge, P. (2004). Elgesys Pokalbis Pasikeitimas. Penki dalinai struktūruoti motyvuojantys pokalbiai. Programos vadovas, skirtas pataisos namams ir pataisos inspekcijoms. Vilnius: KDMC.

Figlie, N. B., Dunn, J., \& Laranjeira, R. (2005). Motivation for change in alcohol dependent outpatients from Brazil. Addictive Behaviors, Vol. 30, 159-165.

Jucevičienè, P. (2013). Požiūris ị ugdymą - edukacinès ir mokymosi aplinkos santykio konceptualusis pagrindas. In: Leonas Jovaiša: nuo pedagogikos edukologijos link. Sud. V. Aramavičiūtè. Vilnius: VUL.

Landenberger, N. A., \& Lipsey, M. W. (2005). The positive effects of cognitive-behavioral programs for offenders: A meta-analysis of factors associated with effective treatment. Journal of Experimental Criminology, Vol. 1, 451-476.

Lietuvos Respublikos Statistikos departamento 2018 metu sausio 1 d. statistiniai duomenys. Access online: https://osp.stat.gov.lt/statistiniu-rodikliu-analize?theme=all\#/.

Lietuvos probacijos tarnybu registro 2018 metu sausio $1 d$. duomenys. Access online: http://www.kaldep.lt/lt/kalejimu-

departamentas/administracine_informacija/ataskaitos/metines.html

Lietuvos Respublikos Probacijos İSTATYMAS. (2011). Valstybès žinios, Nr. 4, 108.

Kalejjimu departamento prie Lietuvos Respublikos teisingumo ministerijos direktoriaus issakymas Nr. V-211 „Dél nusikalstamo elgesio rizikos vertinimo metodiku ir elgesio pataisos programu aprobavimo Lietuvos bausmiu vykdymo sistemoje tvarkos aprašo patvirtinimo ir adaptuotu nusikalstamo elgesio rizikos vertinimo metodiku ir elgesio pataisos programu aprobavimo“. Valstybès žinios, 2012, Nr. 72.

Lipsey, M. W., Landenberger, N. A., \& Wilson, J. S. (2007). Effects of cognitive-behavioral programs for criminal offenders. Campbell Systematic Reviews.

Lipsey, M. W., \& Cullen, F. T. (2007). The Effectiveness of Correctional Rehabilitation: A Review of Systematic Review. The Annual Review of Law and Social Science, Vol. 3, 297320.

Lipsey, M. W., Landenberger, N. A., \& Wilson, J. S. (2007). Effects of cognitive-behavioral programs for criminal offenders. Campbell Systematic Reviews. 
Žukauskiene et al., 2018. Preconditions for Enhancing Socio-Educational Assistance to Individuals Serving Non-Custodial Sentences

Lizama, J., Matthews, V., \& Reyes, S. (2014). What Works? Short-Term, In-Custody Treatment Programs. California State University Fullerton.

Lundahl, B., \& Burke, B. L. (2009). The Effectiveness and Applicability of Motivational Interviewing: A Practice-Friendly Review of Four Meta-Analyses. Journal of Clinical Psychology: in Session, Vol. 65 (11), 1232-1245.

McGuire, J. (2008). A review of effective interventions for reducing aggression and violence. Philosophical Transactions of the Royal Society B: Biological Sciences; 363 (1503): 2577-2597, doi: 10.1098/rstb.2008.0035.

McGuire, J. (2002). Motivation for what? Effective programmes for motivated offenders. In $M$. McMurran (Ed.), Motivating Offenders to Change: A Guide to Enhancing Engagement in Therapy (p. 157-172). Chichester: John Wiley \& Sons.

McConnaughy, E. A., Prochaska, J. O., \& Velicer, W. F. (1983). Stages of change in psychotherapy: Measurement and sample profiles. Psychotherapy: Theory, Research, and Practice, Vol. 20, 368-375.

McMurran, M. (2009). Motivational Interviewing with Offenders. A Systematic Review /Legal and Criminological Psychology. Vol. 14, (1), 83-100.

Miller, W. R., Sovereign, R. G., \& Krege, B. (1988). Motivational interviewing with problem drinkers: II. The Drinker's Check-Up as apreventive intervention. Behavioural Psychotherapy, Vol. 16, 251-268.

Miller, W. R., Brown, J. M., Simpson, T. L., Handmaker, N. S., Bien, T. H., Luckie, L. F., et al. (1995). What works? A methodological analysis of the alcohol treatment outcome literature. In: R. K. Hester \& W. R. Miller (Eds.), Handbook of alcoholism treatment approaches: Effective alternatives (2nd ed., p. 12-44). Boston: Allyn \& Bacon.

Miller, W. R., \& Rose, G. S. (2009). Toward a Theory of Motivational Interviewing. Am Psychology, Sep, Vol. 64 (6), 527-537.

Miller, W. R., \& Rollnick, S. (1991). Motivational interviewing: Preparing people to change addictive behavior. New York: Guilford Press.

Miller, W. R., \& Rollnick, S. (2002). Motivational interviewing: Preparing people for change (2nd ed.). New York: Guilford Press.

Moyers, T. B. (2003). What should be teaching? Using process analysis to guide training. Presentation under ICTAB-konferensen I Heldelberg, September.

Prochaska, J. O., \& DiClemente, C. C. (1984). The transtheoretical approach: Crossing the traditional boundaries of therapy. Malabar, FL: Krieger.

Saarnio, P. (2000). Spelar socialarbetaren nago roll? Nordisk Sosialt Arbeid, N. 1.

Ulgevik, T. (2016). Prisons as Welfare Institutions? Punishment and the Nordic Model. In: Yvonne Jewkes, Ben Crewe, Jamie Bennett (red.) Handbook on Prisons, Routhledge. Access online: https://papers.ssrn.com/sol3/papers.cfm?abstract_id=2767985

Vaitkevičius, R., \& Saudargienè, A. (2006). Statistika su SPSS psichologiniuose tyrimuose: mokomoji knyga. Vilnius: Vytauto Didžiojo universiteto leidykla.

Vasilaki, E. I., Steven, G., Hosier, S. G., Miles, W., \& Cox, W. M. (2006). The Efficacy of Motivational Interviewing as A Brief Intervention for Excessive Drinking: A metaAnalytic Review. Alcohol \& Alcoholism. Vol. 41, (3), 328-335.

Vaske, J., Galyen, K., \& Cullen, T. F. (2011). Toward a Biosocial Theory of offender rehabilitation: Why does cognitive-behavioral therapy work? Journal of Criminal Justice, Vol. 39, 90-102.

Ward, T., \& Maruna, Sh. (2007). Rehabilitation. Beyond the risk paradigm. New York: Routledge. 
Ward, T., Yates, P M., \& Willis, G. M. (2012). The Good Lives Model and the Risk Need Redponsivity model. A Critical Response to Andrews, Bonta and Wormith. Criminal Justuce and Behavior, Vol 1 (39), 94-110.

Wormith, S. M., Althouse, R., Simpson, M., Reitzel ,L. R., Fagan ,T. J., \& Morgan, R. D. (2007). The Rehabilitation and Reintegration of Offenders: The Current Landscape and Some Future Directions for Correctional Psychology. Criminal Justice and Behavior, Vol. 7 (34), 879-892.

Žukauskienè, L., Viršilas, V., \& Farbring, C. A. (2017). Opportunities of socio-educational assistance to individuals serving alternative to imprisonment sentences: the programme behaviour-conversation-change application analysis. Society. Integration. Education. Proceedings of the International Scientific Conference. Volume III, 307-321. 